\title{
UNFAIR LISTS AS INDUCEMENTS TO SECONDARY BOYCOTTS UNDER SECTION 8(b)(4)(A) OF THE TAFT-HARTLEY ACT
}

LABOR unions use a variety of weapons to force employer compliance with their demands. The most widely known economic weapons are the strilie, the picket line, and the boycott. ${ }^{1}$ A less publicized but effective instrument of union pressure is the "unfair" or "We Do Not Patronize" list." This list usually names employers with whom the union is engaged in labor disputes, but does not indicate the nature of the dispute, the issues involved, or what action union supporters might take against the "unfair" employer." The list may be posted on union bulletin boards, distributed to local unions to be read at meetings, published in community or union newspapers, or sent or personally delivered to those having business relations with the listed employer.:

Like the picket line, the unfair list is commonly used today to publicize the existence of a labor dispute: it may stimulate direct community action, such as a consumer boycott; it may keep potential workers from seeking employment with the listed employer. ${ }^{5}$ For such purposes, unfair lists are

1. See Samte, Labor Law 217 (1953); Revolns, Labor Ecusourts and Laro? ReLatTons 287 (1949).

2. For a discussion of the use of "unfair" lists, see Denver Building \& Cunstruction Trades Council, 37 N.L.R.B. 755, 756, 761 (1949). The NLRB there noted that "the unfair listing of a primary employer is a traditional vicapon used by labur organizations

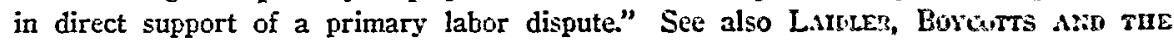
Labor Struggle 115-25 (1913), and Wolaran. The Borcutr ri: Angrica: Trage Uxross (1916), for the early history of the unfair list and its uce in the Lnited States.

3. For an explanation of the unfair list and an indication of its use and effectiveness, see Elliott v. Amalgamated Meat Cutters \& Butcher Workmen, 91 F. Supp. 690, 693 (W.D. MIo. 1950).

4. Amalgamated Meat Cutters \& Butcher Workmen, 93 N.L.R.B. 336 (1951) (list implemented by union meetings and resolutions, and by telephone calls and letters to the members) ; Spokane Building \& Construction Trades Council, 99 N.L.R.B. $116 \$$ (1950) (Council distributed unfair and "We Do Not Patronize" lists quarterly among its afniliated locals with request that they distribute them among memburs); Denver Building \& Construction Trades Council, S2 N.L.R.B. 1195 (1949) (Council circulatcd list to its constituent unions and placed employer's name on the union bulletin board): Briclilayers, Stone MIasons, Marble Masons, \& Tile Layers Benerolent \& Prutcetive Union, \&2 N.L.R.B. 228 (19.19) (copies of minutes of Couneil sent to affiliated uniuns and sometimes read at union meetings, and union newspapers notified); United Brotherhuod of Carpenters \& Joiners of America, \$1 N.L.R.B. \$02 (1949) (Building Trades Council sent copies of its minutes to afiliated unions; sometimes read at union meetings).

5. The Board has stated that it believes the purposes of an unfair list include putting "pressure on the named employer by diverse means, including withdrawal of services from him by union members and by other union-minded employees, reiusal by sush employees to accept his employment, product boycott by union employees and . . the public ...., sympathetic refusal by union employers to trade with him, and the dis- 
probably most effective in small, local disputes. ${ }^{\circ}$ Although conflicts in large industries generally receive full publicity from the regular mass media of communication, disputes in small enterprises attract little public attention. Consequently, the unfair list is often the most important means of spreading news of the union's grievance against an employer. In an area where most of the workers are union members and most families are union-minded, the listing of a small employer can result in pressures from consumers, workers, and business associates that force him to accede to union demands. ${ }^{7}$

Prior to the Taft-Hartley Act, unfair lists were also used rather effectively, especially in the construction industry, to implement secondary boycotts. $^{8}$ By urging members of other unions or locals to force their employer -through a concerted refusal to work-to stop doing business with the persons classified as "unfair," the union could bring into play a powerful economic weapon. But that weapon was capable of injuring completely innocent employers as well as those involved in the dispute. ${ }^{0}$ In response to this problem, Congress in 1947 enacted Section 8(b)(4)(A) of the TaftHartley Act. ${ }^{10}$ That section outlaws any union activity which "induces or

concerting effect of widespread publicity of the labor dispute." Denver Building \& Construction Trades Council, 87 N.L.R.B. 755, 756 n.1 (1949).

6. Laidler, Boycotts and the Labor Struggle 119, 124 (1913).

7. See Wolman, The Boycott in American Trade Unions 82-3 (1916).

8. See United Brotherhood of Carpenters \& Joiners of America, 81 N.L.R.B. 802, 821 (1949) (concurring opinion of Chairman Herzog); Secondary Boycolts in Labor Disputes, Management Review, February, 1938, p. 52; Labor Boycotts Groze, Business Week, November 20, 1937, p. 23.

"The primary or simple boycott is one in which the aggrieved party resolves not to patronize a firm or firms or its product and appeals to its friends to withhold their patronage. The usual secondary boycott is one in which, in addition to the above, coercion, loss of business, etc., are resorted to or threatened to cause third parties to sever business relations." Millis \& Montgomery, Organized Labor 583 (1945).

The secondary boycott has been most often employed as a weapon to compel an employer to recognize or bargain with a union. See Mrillis \& Brown, Frost tHE WaGNER ACt to TAFT-HARTLEy $277-9$ (1950). This device has often been considered unlawful by the state courts, since it is felt that the interest of the union in promoting its organization does not justify the damage incurred by the "disinterested" employer involved. See, e.g., Bricklayers', Masons' \& Plasterers' Int'l Union of America v. Seymour Ruff \& Sons, Inc., $160 \mathrm{Md}$. 483, 154 Atl. 52 (1931) ; Pacific Typesetting Company v. International Typographical Union, 125 Wash. 273, 216 Pac. 358 (1923). MrLus \& Brow N, op. cit. supra, at 460 .

9. See 93 Cong. Rec 4198 (1947); NLRB, Legislative History of tue Ladok MANAGEMENT Relations ACT, 1947, pp. 583, 658, 1056 (1948).

10. 61 STAT. 141 (1947), 29 U.S.C. \& 158 (b) (4) (A) (Supp. 1951): "It shall be an unfair labor practice for a labor organization or its agents ... (4) to engage in, or to induce or encourage the employees of any employer to engage in, a strike or a concerted refusal in the course of their employment to use, manufacture, process, transport, or otherwise handle or work on any goods, articles, materials, or commodities or to perform any services, where an object thereof is: (A) forcing or requiring any employer or selfemployed person to join any labor or employer organization or any employer or other person to cease using, selling, handling, transporting, or otherwise dealing in the products 
encourages" workers to engage in secondary boycotts. Since unfair lists are repeatedly used in connection with such secondary boycotts, the National

of any other producer, processor, or manufacturer, or to cease doing business with any other person; ... Provided, That nothing contained in this subsection [S(b)] shall be construed to make unlawful a refusal by any person to enter uron the premises of any employer (other than his own employer), if the employees of such employer are engaged in a strike ratified or approved by a representative of such employees whom such employer is required to recognize under this Act."

Insofar as lists are concerned, the above section seems in direct conflict with $\S 8(\mathrm{c})$, which provides that any mere expression of arguments or opinions, oral or written, is neither itself an unfair labor practice nor evidence thereof under any of the rrovisions of $\S$ \&. 61 Stat. 142, (1947), 29 U.S.C. $\$ 158($ c) (Supp. 1951). The Supreme Court has ruled, however, that $\S S(c)$ is inapplicable to $\S 8(b)(4)(A)$. "The protection afforded by Section $8(c)$ of the Act to the expression of "any views, argument or opinion" does not pertain where ... the issues raised under Section $\mathbf{S}(b)(t)(A)$ turn on official directions or instructions to a union's own members.' \&2 N.L.R.B. at 1213." National Labor Relations Board v. Denver Building \& Construction Trades Council, 341 U.S. 675, 690-1 (1951). "The prohibition of inducement or encouragement of sceondary pressure by $\$ \&($ b) (4) (A) carries no unconstitutional abridgment of free speceh." International Brotherhood of Electrical Workers v. National Labor Relations Board, 341 U.S. 694,705 (1951).

The literal interpretation of $\$ S(b)(4)(A)$ might outlaw even primary picketing in many cases. But the Board has ruled that primary picketing is not within the scope of this Section. United Electrical, Radio \& Machine Workers of America, 85 N.L.R.B. 417, 418 (1949).

The publication and circulation of an unfair list may subject the union to civil liability for libel. In Paducah Newspapers v. Wise, 247 S.W.2d 989 (Ky. 1951), the Kentucky Court of Appeals decided that unions may be liable for falsely charging an employer with being unfair, "where there exists no controversy or other circumstance which would reasonably justify the intentional damage of the employer's business." Id. at 992, ccrt. denied, 343 U.S. 942 (1952).

If a violation of $\S \&(\mathrm{~b})(4)(\mathrm{A})$ is charged, $\$ 10(1)$ requires the officer or regional attorney to whom the matter is referred to obtain a temporary injunction in a federal district court, providing his investigation discloses reasonable cause for believing the charge is true. In considering relief, the district court will then apply general equity doctrines. See, e.g., LeBaron v. Los Angeles Building \& Construction Trades Council, 84 F. Supp. 629 (S.D. Cal.), aff'd, 181 F.2d 449 (9th Cir. 1949). The decision of the court to issue or not to issue the injunction will have no effect on the subsequent fulldress hearing of the $\$ \&(\mathrm{~b})(4)$ (A) violation charge by the NLRB under $\$ 10(\mathrm{c})$. See United Brotherhood of Carpenters, Lacal No. 74, 80 N.L.R.B. 533, cnforicment groutcd, 181 F.2d 126 (6th Cir. 1948), aff'd, 341 U.S. 707 (1951). If the NLRB finds a violation of 8 (b) (4) (A), $\S 10$ (c) enables it to issue a cease and desist order; and $\S 10$ (e) empowers the Board to petition any United States court of appeals for the cnforcement of such order and for appropriate temporary relief or restraining order. For a detailing of these procedures, see Werne, LAW of LABOR ReLATIONS \$5-6 (1951). Section 303(a) also makes unlawful the activity which constitutes an unfair labor practice under $\$ \$(b)(4)$ (A); and $\$ 303$ (b) provides that any person injured in his business or property by any violation of $\$ 303(\mathrm{a})$ may sue in any United States district court or any other court having jurisdiction of the parties for damages sustained and the cost of the suit. The remedy of damages under $\$ 303$ appears to be completely independent of those attaching to the $\$ S($ b) ( 4 ) (A) complaint. See International Longshoremen's \& Warehousemen's Union v. Juneau Spruce Corp., 342 U.S. 237 (1952). Eut see Xöte, 61 YaLE L.J. 745 (1952). 
Labor Relations Board has been forced to examine the validity under Section 8(b) (4) (A) of various uses of such lists.

The first "unfair listing" case to face the NLRB under Section 8(b) (4) (A) - the Wadsworth case-involved the listing of a secondary employcr. ${ }^{11}$ A majority of the Board viewed that list as "a direction or an appeal to union men not to handle any goods or perform any services for [the secondary employer]."12 Although the opinion did not explicitly make the listing illegal per se, the Board a month later in the Osterink case declared that the mere "unfair" listing of a primary employer ipso facto constituted an illegal encouragement or inducement to a secondary boycott. ${ }^{13}$ Thus it appears that at that time virtually any use of an unfair list would have been unlawful. ${ }^{14}$

But in 1949 in the Grauman case, ${ }^{15}$ the NLRB overruled-at least as to the listing of primary employers-its per se doctrine of illegality. ${ }^{16}$ In Grallman, the Board reasoned that Section 8(b) (4) (A) prohibits only inducement of secondary employees as a group; it does not prohibit devices for publicizing a dispute which are aimed at persuading customers or union members in general to bring pressure upon secondary employers, even when some secondary employees are included among those who are influenced by such publicity. ${ }^{17}$ The Board felt that the listing of an employer directly involved in a dispute is not necessarily for the purpose of promoting pro-

11. United Brotherhood of Carpenters \& Joiners of America, 81 N.L.R.B. 802 (1949), enforcement granted, 184 F.2d 60 (10th Cir. 1950).

12. Id. at 816. Members Houston and Murdock dissented on the ground that frec speech guarantees in $\S 8(\mathrm{c})$ protect all lists. Id. at 822 .

13. Bricklayers, Stone Masons, Marble Masons, \& Tile Layers Benevolent \& Pro* tective Union, 82 N.L.R.B. 228, 230 (1949). Member Houston dissented in part. Id. at 233. Member Murdock took no part.

14. See 15 NLRB Ans. Rep. 145 (1950).

15. Denver Building \& Construction Trades Council, 87 N.L.R.B. 755 (1949).

16. "[A] majority of the Board [Chairman Herzog and Members Houston and Murdock] finds that the Council's action in placing and maintaining Grauman on its unfair list did not, in and of itself, constitute inducement and encouragement within the meaning of Section 8(b) (4) (A)." Id. at 757. Members Reynolds and Gray, dissenting, found the listing not a violation per se, but said the Board should determine legality by exanination of the purpose of listing in each case. Id. at 764 .

17. The NLRB has referred to inducing or encouraging customers, employers, and the general public as legitimate objectives of unfair listing in holding the listing of a primary employer not to be illegal per se. Denver Building \& Construction Trades Council, 87 N.L.R.B. 755, 756 n.1 (1949). Section $8($ b) (4) (A) spealis only of inducement or encouragement of secondary employees. But see Capital Service, Inc. v. National Labor Relations Board, 31 LAB. Rez. Rep. (Ref. Man.) 2326 (9th Cir. 1953), where the picketing of the premises of the secondary employer (a retailer) requesting is consumer boycott of the products of the primary employer, being sold by the retailer, in order to bring pressure upon the employees of the primary employer to bccome unionized, was held to violate $\S 8$ (b)(1)(A). 61 STAT. 141 (1947), 29 U.S.C. $\S 158(\mathrm{~b})(1)$ (A) (Supp. 1951). That section makes it an unfair labor practice for a union "to restrain or coerce (A) employees in the exercise of the rights guaranteed in section 7..." The rights guaranteed in $\S 7$ include the right to refrain from 
scribed action by secondary employees. Instead, the Board noted that "[p] ublication of the fact as to the existence of a primary dispute by means of the unfair list invites secondary action no more than does primary picketing."1s But the NLRB declared that while promulgation of such a list will not itself constitute a violation of the Act, the existence of the list could be used, as it was in Grauman, as the occasion for illegal inducement by union officials. ${ }^{19}$ Thus, under the position taken by the majority, overt acts of inducement in addition to mere publication of the list would seem essential to make out a violation of Section $S(b)(4)(A)$. A minority of the Board was of the opinion that the legality of a list in each case should depend on the union's purpose in promulgating it. 20

In applying the Grauman decision, the NLRB has thus far approved most uses of lists of primary employers which have not been accompanied by specific independent union action, or conversation, advocating secundary action. It has ruled that posting a list naming a primary employer on union bulletin boards and distribution of a list to affiliated unions to be read at meetings are permissible methods of publicizing a dispute."1 The Board has apparently upheld these uses on the ground that they do not seek to "induce" secondary employees as a group, but are aimed at promoting direct consumer action among all union members in a particular locality: Furthermore, implicit in the Board's opinions seens to be the view that the mere

forming, joining, or assisting labor organizations. o1 Sт.AT. 140 (1947), 24 C.S.C. \$ 157 (Supp. 1951).

The Board has also held that inducing an employer or supervisor, even when such action takes place in the presence of employees, is lawiul. Lumber \& Saw mill Workcrs Union, 87 N.L.R.B. 937, 939 (1949). This ruling may reveal a device for evading the statute.

18. Denver Building \& Construction Trades Council, 87 N.L.R.I. 755, 757 (1949).

19. Ibid.

20. Members Reynolds and Gray dissented. They felt that primary empluyer listing would be illegal if primarily intended to induce or uncourage employees of a secundary employer to act in the prohibited manner. Id. at 761-2.

21. Amalgamated Meat Cutters \& Butcher Workmen, 93 N.L.R.B. 33 i (1951) (distribution of list via circulation of minutes and resolutions of union mectings); Spokane Building \& Construction Trades Council, S9 N.L.R.B. 1168 (1950) (distribution quarterly by council of lists of primary employers among its affiliated locals with the request that they distribute them among their nembers); Denver Building \& Construction Trades Council, S7 N.L.R.B. 755 (1949) (primary employer's name placed on union bulletin board and list circulated to affiliated unions). In all three cases, how: ever, the union or its agents engaged in "other conduct" which was found to violate 8 (b) (4) (A).

22. See Denver Building \& Construction Trades Council, 87 N.L.R.E. 755, 756-7 (1949), where the Board majority opinion enumerates the objectives of primary cmployer listing other than inducing or encouraging secondary employees and emphasizes the analogy of an "unfair" list to primary picketing, regarding bath as devices principally intended as means of advertising a labor dispute. This view was reiterated in Amalgamated Mieat Cutters \& Butcher Workmen, 93 N.L.R.B. 336, 337 (1951). 
issuance of a list is an ineffective method of achieving proscribed secondary action. ${ }^{23}$ Although the case has not yet arisen, the publication of a list in a newspaper, which should have even less impact vis a vis secondary employees, would probably be held legitimate. Only in those situations where it has been necessary for a union agent to "remind" workers at a secondary establishment that their employer was doing business with a listed employer has the Board found a violation of Section $8(\mathrm{~b})(4)(\mathrm{A}) .^{24}$

Since Wadsworth was not only the first unfair listing case to reach the Board under Section 8(b) (4) (A) but has also been the only case involving the listing of a secondary employer, it is difficult to tell the present status of such secondary listing. Wadsworth was expressly followed and extended to become a doctrine of per se illegality in the primary listing situation in Osterink. ${ }^{25}$ But the latter case was overruled by the Board in Granman-at least as to primary listing. ${ }^{26}$ And although the Board does seem to place some emphasis in at least one recent case on the fact that a primary employer was listed, ${ }^{27}$ its general approach makes it doubtful that it would apply a por sc doctrine of illegality to the listing of a secondary employer. ${ }^{28}$ In such a situa-

23. The NLRB has never explicitly stated that one of the reasons it has held that these means of distributing a list are lawful is that they do not appear to be effective in causing secondary employees to exert pressure which $8(\mathrm{~b})(4)(\mathrm{A})$ was designed to prevent. Nevertheless, this may be an important factor contributing to the conclusion of legality.

24. Amalgamated Meat Cutters \& Butcher Workmen, 93 N.L.R.B. 336 (1951) (telephone calls to individual workers); Spokane Building \& Construction Trades Council, 89 N.L.R.B. 1168 (1950) (union agents said to secondary employees: "you wouldn't want to work with non-union men on the job here, would you."); Denver Building \& Construction Trades Council, 87 N.L.R.B. 755 (1949) (union agent reminded workers that they were working beside employees of an "unfair" employer); United Brotherhood of Carpenters \& Joiners of America, 81 N.L.R.B. 802 (1949) (employee of secondary employer asked by union representative if "he knew what the situation was"). See also Amalgamated Meat Cutters \& Butcher Workmen, 93 N.L. R.B. 336, 337 (1951).

25. 15 NLRB ANN. Rep. 145 (1950) (discussing Bricklayers, Stone Masons, Marble Masons, \& Tile Layers Benevolent Protective Union, 82 N.L.R.B. 228 (1949)).

26. "To the extent that our finding herein is inconsistent with the decision of the Osterink case finding that the unfair listing of a primary employer ipso facto constituted a violation of Section 8(b) (4) (A), or may itself be found to be illegal because of other evidence showing improper use of the unfair list, that decision is hereby overruled." Denver Building \& Construction Trades Council, 87 N.L.R.B. 755, 757 (1949).

27. "[W]e do not adopt the Trial Examiner's finding that the Respondents violated Section 8(b) (4) (A) of the Act by maintaining Kimsey, the primary employer, on their 'unfair' or 'We Don't Patronize' lists. ..." Spokane Building \& Construction Trades Council, 89 N.L.R.B. 1168, 1169 (1950).

28. Members Reynolds and Gray, two of the majority of three holding primary employer listing an ipso facto violation of $8(\mathrm{~b})(4)(\mathrm{A})$ in Osterink, dissented in Granman, and expressed the opinion that the problems presented by prinary and sccondary employer listing are substantially the same. "The only question to be resolved in either instance then is whether the evidence shows that the unfair listing was intcnded 
tion, however, it is possible that the Board night place somewhat more severe restrictions upon the uses the union might make of the list than if only a primary employer were listed.

Despite the original fears of the Grauman dissenters that the approach adopted by the Board would give inadequate consideration to the purpose for which an unfair list was used in each case, the NLRB's application of Section 8(b) (4) (A) appears thus far to have carried out the legislative policies of the secondary boycott proscriptions. Only individual employees, acting independently, can lawfully attempt to influence their own employer to stop doing business with another employer who is engaged in a primary dispute. And independent action of that sort is extremely difficult to bring about merely by the publication of an unfair list. An additional outside stimulus is customarily needed for the purpose of making the workers aware that they are not in fact acting alone. ${ }^{29}$ Thus, under most circumstances in which a secondary boycott is a real possibility, there is "other conduct" 30 accompanying an unfair list; and it is that conduct which the Board generally finds to be an unlawful inducement, or encouragement, to a secondary boycott.

It is possible, however, that a purely mechanical application of the NLRB's present formula for determing legality might permit some unions, through skillful use of the unfair list, to effectuate secondary boycotts with impunity. MIany unions have by-laws prohibiting their members from working directly or indirectly for "unfair" employers or employers who have been placed on an unfair list." Although such provisions are in practice generally not selfexecuting, a tight local union might make the mere listing of a primary employer on a union bulletin board the signal for concerted action by members against secondary employers. In such a case, the listing itself might represent

to induce or encourage employees of secondary employers within the meaning of $\$$ 8(b) (4) (A). Only to the extent that the proof of illegality in the case of the listing of a primary employer may be more difficult than in the case of the listing of a secondary employer, do we believe that a distinction is warranted" (Emphasis sugplied.) Denver Building \& Construction Trades Council, 87 N.L.R.B. 755, 763 (1949) (dissent).

29. See note 24 supra.

30. "Other conduct" has most often consisted of direct communiations to employees of secondary employers while on the job. See nute 24 supra.

31. The constitution of the Ericklayers International provides that no member shall work for anyone employing non-union employees in any branch of trade within the jurisdiction of the International or work for a subcontractor who takes a contract from any person or firm employing non-union employees or work for any firm or persin either directly or indirectly who has been placed on the unfair list by the International. See Trial Examiner Scharnikow's enumeration of such regulations of various unions, Bricklayers, Stone Masons, Marble Masons, \& Tile Layers Benevolent \& Protective Union, \&2 N.L.R.B. 228, 239-40 (1949). Such provisions of union constitutions or bylaws, like a union's designation of an employer as unfair, are not illegal fer se but may furnish the inducement or encouragement for a strike or concerted refusal to worl: Joliet Contractors Ass'n v. National Labor Relations Board, 31 Lns. Rel. Rep. (Ref. Ifan.) 2361, 2363 (7th Cir. 1953). 
a "verbal act" precipitating a secondary boycott. ${ }^{32}$ The Board's current ap" proach may be sufficiently flexible to meet such a situation. But present emphasis upon the specific acts of union inducement often used in connection with unfair lists may lead the Board to overlook the possible importance of the full context in which the list is used. Furthermore, the NLRB now runs the risk of undue emphasis on stare decisis. Merely because a particular use of a list - for example, distribution of the list to be read at the meetings of affiliated unions - is held lawful in one case, does not mean it should be lawful in all cases. ${ }^{33}$

Although the Board has blocked most attempts to use the unfair list as an occasion for a secondary boycott, it has left the way open for at least two uses of the list which seem to contravene the policy of Section $8(\mathrm{~b})(4)$ (A). The first results from the NLRB decision in the Converay case. ${ }^{34}$ An employer had entered into a contract with his employees under the terms of which the employees could refuse to handle the productslabeled "hot cargo"35 - of any other employer with whom the union hat a dispute. Acting under the contract, the workers achieved in effect a secondary boycott. The Board opinion, which was affirmed by the Second Circuit, took the position that the secondary employer had consented in advance to boycott the primary employer ${ }^{36}$ And the proscription in the Act against bring-

32. As long ago as 1911, the Supreme Court recognized this potentiality in unfair lists. Justice Lamar, speaking for the Court in the famous Buclis Stove case, stated: "In the case of an unlawful conspiracy, the agreement to act in concert when the signal is published, gives the words 'Unfair,' 'We do not patronizc', or similar expressions, a force not inhering in the words themselves, and therefore excecling any possible right of speech which a single individual might have. Under such circumstances, they become what have been called 'verbal acts' . . . ." Gompers v. Bucks Stove \& Range Co., 221 U.S. 418, 439 (1911).

33. The language of at least one decision appears to indicate that the Board may be moving toward such a mechanical stare decisis approach which ignores possible refinements and distinctions. Amalgamated Meat Cutters \& Butcher Workmen, 93 N.L.R.B. 336, 337 (1951).

34. International Brotherhood of Teamsters, 87 N.L.R.B. 972 (1949).

35. "Hot cargo" is the term applied to goods or materials produced by an enployer with whom the union is engaged in a labor dispute. A "hot cargo" list usutlly ennumerates the products manufactured by such an employer. WERNE, THE LAW OF LABOR Rezations 239 (1951).

36. The fact that this contract was entered into prior to the passage of the TaitHartley Act was immaterial to the decision. According to the Board: "[T]here is nothing in the express provisions or underlying policy of Section $8(b)(4)(A)$ which prohibits an employer and a union from voluntarily including 'hot cargo' or 'struck work' provisions in their collective bargaining contracts, or from honoring these provisions." International Brotherhood of Teamsters, 87 N.L.R.B. 972, 982-3 (1949).

Chairman Herzog and Member Reynolds disagreed with the Board majority ruling that the contract in this case constituted a defense to the unfair labor practico charge. Id. at 983 n. 33, 995.

The Conway case was appealed to the Second Circuit, where the Board decision was affirmed both as to the determination that an oral "closed-shop" contract was in cx- 
ing pressure for a secondary boycott by "a strike or concerted refusal" did not prevent the union from achieving a similar result through collective bargaining procedures. One result of the Conaray decision may be that a union can with impunity send an unfair list to secondary employees and recommend that a secondary boycott be effected, provided the secondary employees have a Conway-type contract to support their action. ${ }^{3 \pi}$

Whether or not the action taken under the contract was with the consent of the employer, as the Board felt, such a use of Coniay would seem in conflict with the objectives of the statute. Even though such a contract is in effect, the union of either the primary or secondary employees would probably have to communicate with the workers of the secondary employer in order that a strike or refusal to handle the goods of the primary employer may be effecuated. And should the technique used for such communication be such that it would constitute an "inducement" in violation of Section $8(\mathrm{~b})(4)(\mathrm{A})$ in the absence of a Conway-type contract, there would seem to be just as much of an inducement in its presence. Furthermore, even assuming this activity literally complies with $S(b)(4)(A)$, the Conatay-type contract itself should probably not be recognized, since it authorizes activity "repugnant to the basic public policies of the Act." 38

istence and enforceable, and as to the holding that the contract and the union activities based thereon did not violate S(b) (4) (A). Rabouin v. National Labor Relations Board, 195 F.2d 906 (2d Cir. 1952). Judge Clark, for the majority, upheld the NLRE on the latter point on the strength of omission from the House version of the Tait-Hartley Bill of a rule against threats to strike (H.R. 3020, S0th Cong., 1st Sess. $\$ \$ 2(14), 12(3)$ (3) (1947)). 195 F.2d at 912. Judge L. Hand dissented, finding that the union had repudiated the "closed-shop" contract and that this rendered consideration of the other points of the case unnecessary. Id. at 913-4.

37. As a result of the Conziay decision, the union which has secured sush a contrast may employ direct action to achieve a secondary boycott. It scems to follow from this determination that the sending of an unfair list by the union engaged in tire primary dispute to a union which possesses such a contract, or its members, induring them to exercise their contractual rights, likewise might be viewed as not prohibited by $\$ \&($ b) ( + (A). For a critical discussion of the Conaday decision, see Tower, $A$ Perspectize on Secondary Boycotts, 2 LAB. L.J. 727, 737 (1951); Note, 38 VA. L. Rex. 481, 49990 (1952).

38. Member Reynolds, concurring in part and dissenting in part: "To the extent that these contract provisions authorize such activity, they are repugnant to the basic public policies of the Act. As the Bcard in the public interest is charged with the duty of preventing unfair labor practices, contracts which are repugnant to the let and which conflict with this duty of the Board must obviously yield." International Brotherhood of Teamsters, 87 N.L.R.B. 972, 995 (1949). It should be noted, however, that Congress did not prohibit secondary employers from voluntarily refusing to do business with a disputing primary employer; nor did it prohibit direct union action to influence a secondary employer. The only action outlawed was inducement of sccondary employees to coerce their employer. Hence, if an employer consents to a Corasistype contract, it is at least arguable that not even the policy of $s(b)(4)(A)$ is been violated. 
A second method by which an unfair list may be used to effectuate a secondary boycott is by sending the name of a primary employer to secondary employees, urging them to refuse to perform any work at the prenisiss of thc primary employer. The Board decided in the Pure Oil case "s0 that a "hot cargo" list, which encouraged workers of a secondary employer not to handle goods of the primary employer at the latter's place of business, did not violate $8(\mathrm{~b})(4)(\mathrm{A})$, since it merely invited action at the situs of the primary dispute. Activity which takes place at the plant of the primary employer has generally been regarded as direct action-comparable to primary picketing or the fundamental right to strike-and hence not prohibited by $8(\mathrm{~b})(4)(\Lambda) .^{40}$ And the Board felt that this doctrine should properly be extended to cover such use of a "hot cargo" list.

In the Rice Milling case, ${ }^{41}$ decided in June, 1950, the Fifth Circuit, reversing a decision of the NLRB, rejected the Board's view that the locus of any attempt.to induce or encourage action directed toward a secondary employer should make any difference. It found that union pickets at the site of a primary dispute violated Section 8 (b) (4) (A) by inducing two truck drivers working for a secondary employer not to cross their picket line. ${ }^{42}$ The Supreme Court reversed the Fifth Circuit on the ground that the inducement was not to concerted action as required by Section $8(\mathrm{~b})(4)(A) .^{43}$ But the

39. Oil Workers Int'1 Union, Local Union 346, 84 N.L.R.B. 315 (1949).

40. See United Electrical, Radio \& Machine Workers of America, 85 N.L.R.I. 417 (1949), where the premises of the primary and secondary employer were the same, though the employees of the secondary employer used a separate cutrance, and picketing by the union of the primary employees at this adit was found lawful under the primary situs rule.

For further insight on what is considered primary situs by the Board, see International Brotherhood of Teamsters, 90 N.L.R.B. 401 (1950); International Brotherhood of Teamsters, 87 N.L.R.B. 502 (1949); Note, 38 VA. L. REv. 481, 486 et scq. (1952).

41. International Rice Milling Co. v. National Labor Relations Board, 183 r.2d 21 (5th Cir. 1950), rev'd on other grounds, 341 U.S. 665 (1951).

42. "The statute clearly provides a remedy for the type of conduct engaged in by the union, without resort to any distinction between primary and secondary activities.

“. .

"To allow the Board to rule such activity as prohibited by the statute not to be a violation thereof, simply because it occurred in the vicinity of the struck employer's plant, would render the section ineffective and insufficient." Id. at 26-7. The Seventh Circuit is likewise in disagreement with the Board's primary-secondary distinction. Joliet Conttractors Ass'n v. National Labor Relations Board, 31 LAB. REL. Rep. (Ref. Man.) 2361, 2364 (7th Cir. 1953). For critical discussion of the primary situs test, see Note, 38 VA. L. REv. 481, 486-8, 495 (1952).

43. National Labor Relations Board v. International Rice Milling Co., 341 U.S. 665 (1951). Appeal was taken on the limited question of whether the Fifth Circuit's finding was correct that conversation and rock throwing directed toward the two truck drivers by union members engaged in picketing the primary employer's plant violated $\$ \S 8(\mathrm{~b})$ (4) (A), (B). The Supreme Court decided that the union's inducement or encouragentent of individual workers of secondary employers as they approached the primary picket line was not aimed at concerted activity as prohibited by the statute, $i d$. at 671 , although the con= 
Court did not pass on the validity of the Court of Appeals' "situs" holding. And the NLRB's decision in the Nez'spaper Delizerers case, 1 after the Fifth Circuit opinion, indicates that it will continue to apply the primary situs test.

In view of the Supreme Court's holding in Rice Mrilling, virtually any noncoercive persuasion by primary pickets of individual secondary employees attempting to cross the picket line will probably escape the proscriptions of Section 8 (b) (4) (A). But the validity of direct appeals, outside a primary picketing context, by which the union asks the workers of a secondary employer not to perform any work at the premises of the primary employer - seems more questionable. ${ }^{45}$ Since directed to a group of employees, such appeals would seem to be aimed at obtaining "concerted" action by almost any definition. Furthermore, the language of Section $S(b)(4)(A)$ appears to comprehend all forms of inducement to secondary workers to bring pressure on their employers, without regard to the situs of either the inducement or the concerted refusal to work. The right to picket is a recognized exception to this prohibition. And although the Supreme Court's opinion in Rice Milling was not based on the fact that the inducement involved amounted to an integral part of the picketing, such a picketing rationale might be used to permit peaceful persuasion by pickets even in a case where the required "concerted" action was present. ${ }^{46}$ But where there is attempted persuasion not by

certed activity question was apparently not even argued in the briefs. For criticism of the concerted activity ruling, see Koretz, Federal Regulation of Sccondary Siriles and Boycotts-A New Chapter, 37 CoRNell L.Q. 235, $249-53$ (1952).

44. Newspaper \& Mail Deliverers' Union of New York \& Vicinity, 90 N.L.R.B. 2135 (1950). The union was engaged in a dispute with the owners of subway newsstands, and the primary situs rule was employed to justify the successiul inducement of employees of newspaper publishers not to make deliveries to the newsstands with which the union was engaged in a primary dispute.

45. The NLRB recognized this distinction and was careful in its brivf for the Ritic Milling case to distinguish the facts of that case from those in the Purc Oil case, implying that the legality of the union's activities in the latter case was mure doubtiul. Brief for Appellants, pp. 47-8, National Labor Relations Board v. International Kice Milling Co., 341 U.S. 665 (1951).

If the Supreme Court interprets inducement to concerted astivity to mean indurement of employees as a group, as it appears to have done in the Rice Millis:y dscision, many, if not most, secondary boycotts which a union of primary employees desires may be effected by direct communication to one or a few secondary employees, without infringement of $\mathcal{S}(\mathrm{b})(4)(\mathrm{A})$. It is more probable that Congress intended, as the Eoard has held, that "concerted" at most calls for inducement of mure than one secondary employee. United Brotherhood of Carpenters \& Joiners of America, Bl N.L. R.B. S02, 818 (1949). See also Amalgamated Meat Cutters \& Butcher Workmen, 93 N.L.R.B. 336, 337 (1951). For a recent interpretation of the "coneurted" rcquircment as laid down in Rice Milling, see Joliet Contractors Ass'n v. National Labor Relations Board, 31 LAB. ReL. Rep. (Ref. Jian.) 2361 (7th Cir. 1953).

46. "[Picketing] consists of the stationing of one or more representatives of the workers at a strategic point to perform one or more of several functions. Piclsets . . . may observe [the dispute] to see the extent of operations and the persons who come there for business. They may also, by word of mouth, or signs or placards, seek to dissuade 
pickets but by union-sent letters or union notices which specifically ask the employees of a secondary employer to refuse to work for their employer at the situs of the primary dispute, the inducement cannot be said to be a legitimate part of the right to picket. Unlike picketing and the normal perstuasion incident to picketing, inducement such as involved in Pure Oil is not an integral part of the right to strike. And unlike the mere distribution of an unfair list, such communication does directly exhort secondary employees to take action against their own employers. Since the union action clearly falls within the broad language of Section 8(b)(4) (A) and is not justified by any exception to that provision, it should be held an unfair labor practice. ${ }^{47}$

Louis Emanuer, III $\dagger$

workers and others from entering the plant for purposes of business or from otherwise doing business with the employer." Restatement, Torts $\$ 779(2)$ (f), Comment (1939). See also Koretz, Federal Regulation of Secondary Strikes and Boycotts $-A$ Nezv Chapler, 37 CORNELL L.Q. 235, 245 (1952).

47. The "fair" list-which names employers on amicable terms with the union-is a third device which might be used to avoid the Board's secondary boycott rules. It is usually distributed for display purposes to the "fair" employers themselves, or to those likely to have business dealings with them. Since it only indirectly calls attention to union disputes with employers omitted from the list, and probably is aimed more at customers than at secondary employees, the "fair" list will undoubtedly be upheld if its legality under $8(b)(4)(A)$ is tested. Recognizing this, and troubled by the litigation which "unfair" lists have provoked, some unions are using "fair" lists with increasing frequency. In any area where the "fair" list is a firmly established union weapon and workers check it closely, it may promote a secondary boycott as effectively as more direct instigation. In the large majority of cases, however, the use of the "fair" list seems to violate neither the language nor the purpose of $8(\mathrm{~b})(4)(\mathrm{A})$.

† Member of the Class of 1954, Yale Law School. 